\title{
ALKIBIADOV PEDAGOGICKÝ EROS?
}

ANDREJ KALAŠ, Katedra filozofie a dejín filozofie Univerzity Komenského v Bratislave, Bratislava, SR

ZUZANA ZELINOVÁ, Katedra filozofie a dejín filozofie Univerzity Komenského v Bratislave, Bratislava, SR

\author{
KALAŠ. A., ZELINOVÁ, Z.: Alcibiades' Pedagogical Erôs? \\ FILOZOFIA, 74, 2019, No. 1, pp. $13-27$
}

The main aim of this study is to point out the specific relationship between Alcibiades and Socrates' educational art in Plato's dialogues (especially Alcibiades I. and Symposium) and in Aeschines' fragments. The contribution postulates the hypothesis that an essential precondition for Socrates' education to the virtue (to the aretê) is an erotic reciprocity, which manifests itself through the sight (opsis) from the eyes to the eyes of erastês and erômenos. For this reason, we are trying to answer the question: How is Socrates the philosopher educated by arrogant Alcibiades?

Keywords: Alcibiades - Paideia - Erôs - Aeschines - Opsis - Love - Therapy

Pedagogické, teda aj terapeutické účinky ${ }^{1}$ Sokratovej $\dot{\varepsilon} \rho \omega \tau$ pretačnej literatúre pomerne oblúbenou témou, ktorej v poslednom období venuje svoju pozornost' čoraz viac a viac svetových, ${ }^{2}$ ale aj slovenských ${ }^{3}$ bádatelov. Výskum v oblasti sokratovského terapeutického umenia, tak ako ho nachádzame zachytené u Platóna, ale aj u iných sokratikov, akými sú napríklad Antisthenés, Xenofón či Aischinés, sa začal rozvíjat' priamo úmerne s narastajúcou popularitou filozofie Michela Foucaulta. Foucault ${ }^{4}$ vo svojich posledných prednáškach poukázal

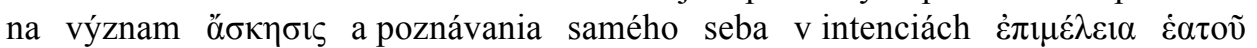
v gréckej filozofii a otvoril tak úplne nový interpretačný rámec. $v$ tomto rámci sa Sokrates vníma ako jedinečný terapeut, ktorý dokáže prostredníctvom špecifického pôrodníckeho umenia a sokratovskej lásky viest' svojich žiakov, respektíve pacientov $\mathrm{k}$ tomu, aby sa stali morálne zdatnejšími. Nevyhnutnou súčastou tohto

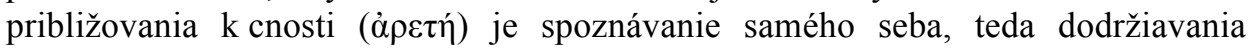

\footnotetext{
${ }^{1}$ Sokratovo pedagogické umenie nie je založené na sprostredkúvaní faktických poznatkov, ale práve na terapii, ktorá sa usiluje viest’ žiaka k dobrému životu.

${ }^{2}$ Porov. Nehamas (2000) alebo Sellars (2009).

${ }^{3}$ Porov. Suvák (2014, 2017, 2016, 2017); Wollner (2010); Flachbartová $(2014,2016)$ a Flachbartová, Sisáková, Suvák (2016).

${ }^{4}$ Porov. Foucault $(2002,2008)$. K využitiu foucaultovského interpretačného rámca pri výklade Aschinovho diela pozri napr. Lampe 2015, 61 - 81. Antickou filozofiou a terapeutickým umením sa zaoberá aj Hadot, pozri Hadot (1987). K tejto otázke porovnaj tiež Zvarík (2018).
} 


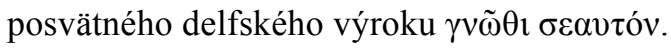

Najznámejšia literárna, a tiež historická postava, ktorá sa - v negatívnom či pozitívnom zmysle slova - spája so Sokratovou výchovou, je Alkibiadés, pričom toto prepojenie s antickým konceptom $\pi \alpha 1 \delta \varepsilon i ́ \alpha$ nachádzame takmer u každého autora

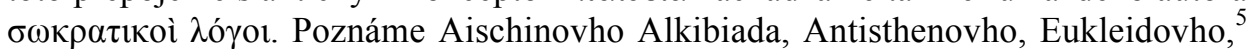
Faidónovho, ${ }^{6}$ Xenofónovho a najzachovalejší je pravdepodobne Platónov portrét. Historici antickej filozofie sa zhodujú v názore, že všetky sokratovské tituly o Alkibiadovi predstavovali akúsi jednotnú odpoved' sokratovského krúžku na Polykratovu žalobu s ciel'om dokázat' Sokratovu nevinu - Alkibiadove negatívne vlastnosti neboli dôsledkom Sokratovej výchovy, práve naopak, stretávanie so Sokratom ich vedelo potlačit', teda jeho $\pi \alpha 1 \delta \varepsilon i ́ \alpha$ mala na mladého aristokrata bez akýchkol'vek pochýb pozitívne účinky ${ }^{7}$.

Zdá sa teda, že o pozitívnom vplyve Sokrata na Alkibiada (aspoň podl’a svedectva sokratovského krúžku) nemožno pochybovat'. Podobne však nemôžeme pochybovat' ani o zhýralosti a skazenej povahe tohto významného člena rodiny Alkménovcov. Plutarchos nás $\mathrm{v}$ zhode ${ }^{8} \mathrm{~s}$ Corneliom Nepom informuje, že nikto $\mathrm{v}$ Aténach nad ním nevynikal ani prednostami, ale ani vadami ${ }^{9}$ (nihil illo fuisse excellentius vel in vitiis vel in virtutibus) (Nep. Alc. 1). V podobných negatívnych súvislostiach hovorí o Alkibiadovej povahe aj Platón, pričom poukazuje najmä na

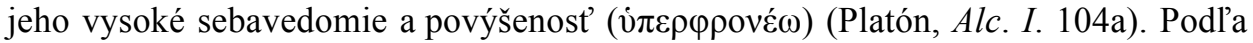
Xenofóna môžeme Alkibiada označit' za toho, kto sa vôbec nevedel ovládat'

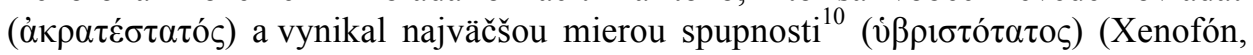
Mem. I. 2. 12).

Napriek Alkibiadovým nesporným negatívnym vlastnostiam predpokladáme, že „charakter Alkibiada“, ako ho nachádzame vykreslený u jednotlivých sokratovcov, má významné miesto v rámci sokratovskej paideie. Ciel’om nášho príspevku sa tak stáva hl'adanie odpovede na kontroverznú otázku: Akým spôsobom spupný Alkibiadés vychováva filozofa Sokrata? Zatial' čo väčšina súčasných bádatel'ov sa na Alkibiada pozerá ako na objekt či prijímatel'a sokratovskej výchovy, naším zámerom je, naopak, vidiet' v ňom toho, kto sám špecifickým spôsobom pôsobí na Sokrata a v istom zmysle ho dokonca (hoci neintencionálne) vychováva. V našom príspevku sa zameriame na Platónov a Aischinov portrét Alkibiada.

\footnotetext{
${ }^{5}$ Porov. Diog. Laert., Vit. II.108.

${ }^{6}$ Porov. Diog. Laert., Vit. II. 105.

${ }^{7}$ Kalaš - Suvák $(2013,473)$ a tiež Jirsa $(2007,279$ - 292).

${ }^{8}$ Plutarchos, Alc. 23.

${ }^{9}$ Porov. Platón, Hipp. Min.369b, konkrétne myšlienku, že jeden a ten istý človek je naraz aj lživý aj pravdivý.

${ }^{10}$ Porov. Ael. Aristid. De quatt. 575.
} 
Sokrates a Alkibiadés alebo filia a Eros. V nasledujúcej časti sa budeme venovat' analýze vzt'ahu, ktorý vzniká medzi Sokratom ako vychovávatel’om a jeho žiakom - v tomto prípade pôjde o Alkibiada. Nazdávame sa, že objasnenie špecifického charakteru daného vzt’ahu v sokratike prispieva k vysvetleniu Alkibiadovho netradičného paideutického potenciálu a zároveň rozširuje predstavu o spôsobe výchovy v sokratovskej filozofii ako takej. Súčast'ou tejto analýzy bude hladanie odpovede na otázku, akým spôsobom sokratovská filozofia (v tomto prípade Platón) modifikovala koncept Erosa, ktorý hral signifikantnú úlohu $\mathrm{v}$ tradičných pedagogicko-pederastických vzt’ahoch. Zároveň budeme implicitne predpokladat', že Alkibiadés, tak ako ho nachádzame v platonizme, istým spôsobom symbolizuje archaického Erosa, pričom pri tomto predpoklade vychádzame najmä z Alkibiadovho dramatického vykreslenia v dialógoch Alkibiadés I. a Hostina. ${ }^{11}$

Predpokladáme, že špecifiká tohto vzt’ahu sa ukazujú prostredníctvom vzájomného prepojenia medzi zrakom a pedagogickou funkciou Erosa ${ }^{12} \mathrm{v}$ Platónovej filozofii.

So slovami „zrak“, „pohl'ad“ a „pozeranie“ sa v starogréčtine spájalo niekol'ko výrazov. Okrem slovies $\varepsilon \delta_{\delta} \omega$ (vidím) alebo $\beta \lambda \varepsilon \dot{\pi} \omega$ (pozerám) Platón vo viacerých dialógoch (Alkibiadés I., Faidros) používa ő\%ic (zrak, pohl'ad). To isté slovo už u Homéra označuje silu zraku alebo videnia (Il. XX. 205; Od. XXV. 94).

Zdá sa, že ešte pôvodnejší bol termín ö $\pi 1 \varsigma^{13}$, ktorý niesol najmä negatívne konotácie. U Homéra (Il. XVI. 388; Od. XX. 215) a Hésioda (Op. 187 a 251) odkazuje najmä na pomstu bohov, ktorí všetko vidia a trestajú porušenie božích zákonov. Iba ojedinele sa vyskytuje v pozitívnom kontexte - Pindaros hovorí o zbožnom pohl'ade (Isth. V. 58) alebo uvedeným pojmom vyjadruje priazeň bohov

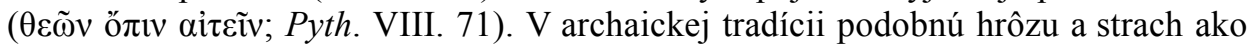
spomínaný trest bohov niekedy vyvoláva aj Eros. Tento negatívny aspekt Erosa sa

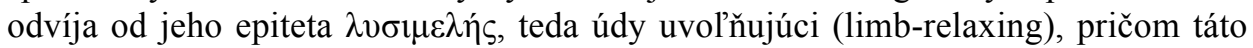
schopnost' je priamo napojená na orgán zraku - v Hésiodovej Theogonii charitkám

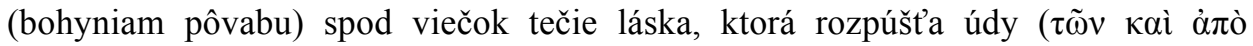

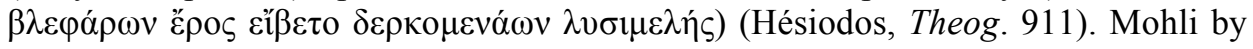

\footnotetext{
${ }^{11}$ Platónov Alkibiadés je krásny, nevie sa však ovládat' (porov. Symp. 213d), je opitý a plný túžby (porov. Symp. 212d, 218e a i.). Vd’aka kráse je objektom túžby (porov. Alc. I. 103b), vd'aka uvedeným negatívnym vlastnostiam zasa vyvoláva strach. V tomto zmysle by sme mohli vidiet' isté paralely medzi Alkibiadom a Erosom, ako ho vníma poetka Sapfó, ked' hovorí o strachu z tohto boha napriek tomu, že vyvoláva túžbu (Sapph. 40).

12 Platónov Sokrates sa v dialógu Hostina priznáva, že jediné, v čom sa vyzná, sú veci lásky

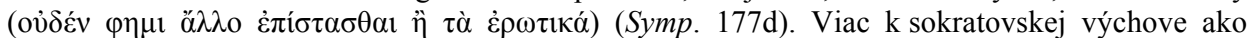
k vykonávaniu ta erótika pozri Suvák $(2018,11)$.

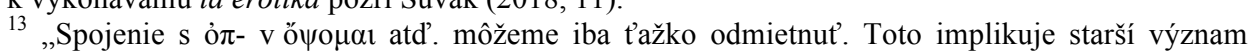
„Zraku, pozerania a pohl'adu“ odkial' pochádza na jednej strane „kritika a trest“ a „úvaha, rešpekt a úcta" na strane druhej. Rozvoj významu podstatného mena bol čiastočne ovplyvnený výrazom

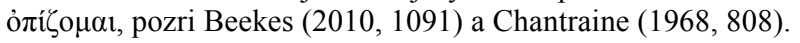


sme povedat', že uvedený boh túžby vzbudzuje strach, pretože prostredníctvom zraku, oka či pohl'adu oslabuje mytologických hrdinov (ale aj bohov) a ohrozuje tak vykonávanie ich hrdinských činov ${ }^{14}$. V Odysei pohl’ad na krásnu Penelopu vyvoláva u ženíchov túžbu, ktorá im oslabuje údy: „Ženíchom na mieste ochabli údy, tak

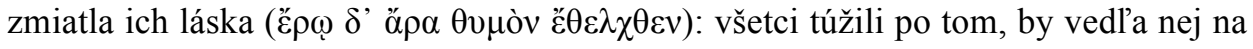

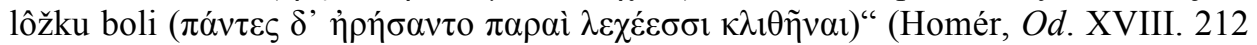
- 213). V Iliade je to opät' láska, ktorá prostredníctvom pohl'adu zastiera Diovu rozumnú mysel' (Il. XIV. 294). Podobné nebezpečenstvo vidia v Erosovi aj predstavitelia archaickej lyriky. Podl'a Alkmana sú účinky tohto boha horšie ako tie, ktoré vyvoláva smrt' (Alkman, Frg. 3). Alkaios zasa uvádza Erosa ako príčinu, že Helena stratila zdravý rozum (Alkaios, Frg. 283). Prepojenie medzi nástrahami Erosa a zrakom nachádzame aj v Chvále Heleny od Gorgia: „Ak sa teda Helenine oči potešili pohl'adom na Alexandrovo telo a vzbudili v jej duši horlivú snahu dosiahnut' lásku, máme sa ešte čomu čudovat?"“ (Gorg., Hel. § 19) Tento vzt’ah medzi okom, resp. videním a Erosom pretrváva dokonca ešte u Aristotela, ktorý l'udské oko pokladá za najsexuálnejší orgán hlavy, pretože obsahuje najviac semena

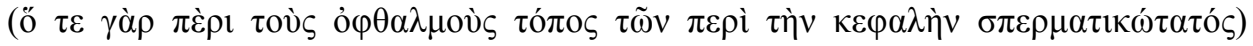
(Aristotelés, De Gen. Anim. 747a13). V gréckom myslení sa teda bežne vyskytovala predstava, že pohl'ad na objekt túžby má za následok oslabenie alebo dokonca úplnú

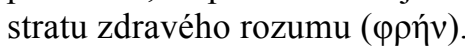

V antickej literárnej a filozofickej tradícii teda môžeme identifikovat' prinajmenšom dva prístupy odkazujúce na vzt’ah medzi zrakom a erotickou láskou: a) archaický koncept Erosa, pri ktorom pohl'ad na objekt lásky vedie k strate zdravého rozumu a b) platónsko-sokratovský koncept erotickej lásky, ktorá by - ako uvidíme neskôr - mala mat' pozitívny vplyv na rozumové kompetencie milencov, a teda aj na formovanie cnostnej duše.

Na prvý pohl’ad sa zdá, že Platónov Sokrates radikálne odmieta archaický koncept Erosa - Sokrates netúži po krásnom tele, ale po krásnej duši; Sokratov zdravý rozum tak nemôže ohrozit' ani oslabit' pohl'ad do očí krásneho spolubesedníka; pre Sokrata nie je dôležitý fyzický zrak, pretože l'udské oko vníma najmä „herakleitovský“ svet diania, no práve duševný zrak má v platonizme významné postavenie.

My sa však nazdávame sa, že v Platónovej filozofii má fyzický zrak, teda zrak, ktorý nevníma krásu myšlienok, ale krásu tela, stále významnú úlohu. Navyše na niektorých miestach je v nej možné identifikovat’ podobný strach, ktorý vzbudzoval mytologický alebo archaický Eros. Naše tvrdenia sa pokúsime zdôvodnit' najmä prostredníctvom analýzy dialógov Alkibiadés I., Hostina a Faidros, vd’aka ktorej zároveň objasníme vzt’ah medzi vychovávatel’om a žiakom v sokratovskej tradícii.

\footnotetext{
${ }^{14}$ Vítek píše, že toto oslabovanie sa deje strácaním životodarných tekutín, ako sú slzy alebo sperma. Pozri Vítek $(2010,51)$
} 
Dialóg Alkibiadés $I^{15}{ }^{15}$ vykresl'uje počiatky pedagogického vzt'ahu medzi Platónovým Sokratom a budúcim politikom Alkibiadom. Práve v úvode tohto dialógu sa ukazuje spomínaný charakter archaického Erosa, ked' Sokrates vysvetl'uje, prečo sa k mladému Alkibiadovi dosial' nepriblížil. „Azda sa čuduješ,

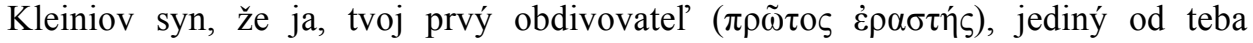
neodchádzam, kým ostatní sa t’a zriekli, a že kým ostatní t’a obt’azovali svojimi dotieravými rečami, ja som celé roky neprehovoril s tebou ani slovo. Príčina, ktorá ma od toho zdržiavala, nebola $\mathrm{v}$ nejakom l’udskom vplyve, ale bola to akási božská

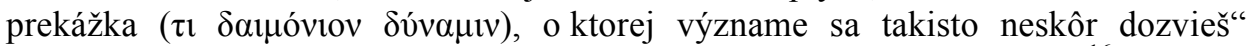
(Platón, Alc. I. 103a). Odborníci z oblasti dejín antickej filozofie ${ }^{16}$ zvyknú dramatický dej tohto dialógu datovat' približne okolo rokov 430/429 pred Kristom. Dej dialógu by sa mal odohrávat' asi dva roky po Alkibiadovej účasti v bitke pri Poteidaii, ktorá sa odohrala krátko pred začiatkom peloponézskej vojny.

Sám autor dialógu využíva na dokreslenie dramatického deja ustálený literárny

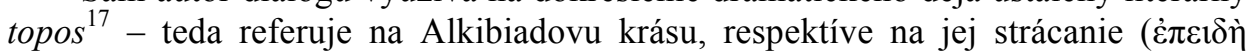

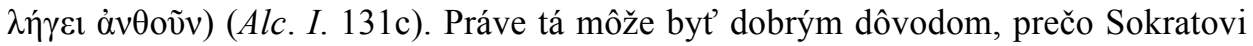
daimonion bránilo priblížit' sa $\mathrm{k}$ Alkibiadovi. „Tak ja som jediný, ktorý od teba neodchádza, ale zotrváva pri tebe, aj ked' pominie pôvab tvojho tela, kým ostatní sa od teba odvrátili [...] ja jediný som bol zamilovaný do teba, kým ostatní boli zamilovaní len do toho, čo je tvoje. To tvoje však stráca pôvab, ale ty sám začínaš kvitnút'. A nikdy t’a neopustím, ak sa teraz nedáš skazit' aténskym l'udom a ak sa nestaneš škaredším“" (Alc. I. 131d-132a).

Na predchádzajúcich riadkoch sa zasa dozvedáme, že Alkibiadés má okolo dvadsat' rokov (Alc. I. 123d). Starogrécky výraz $\mu \varepsilon ı$ ákiov (niekedy sa používalo

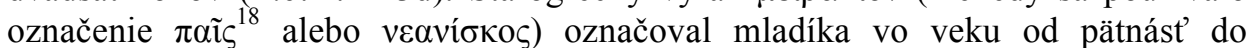
približne dvadsat' (niekedy až dvadsatjjeden) $\operatorname{rokov}^{19}$. Je to práve toto obdobie v živote mladého muža, ktoré sa spájalo s pederastickými ${ }^{20}$ účinkami Erosa. Avšak

\footnotetext{
${ }^{15}$ Tento dialóg je väčšinou považovaný za „semiautentický“. V prvej polovici 20. storočia viacerí autori ako napríklad Friedländer $(1921$ - 1923) a Stefanini (1932) pomerne presvedčivo argumentovali v prospech jeho autenticity. Thesleff sa však nazdáva, že jediné, čo dokázali vylúčit', je jeho postplatónsky charakter. Za najzávažnejšie argumenty proti jeho autenticite považuje nedostatok dôvtipu a fakt, že dialóg sa čítal ako učebnica sokratovskej a platónskej filozofie (Thesleff 2009, 361 - 362). Avšak takmer podl'a všetkých interpretácií autor dialógu dobre poznal sokratovsko-platónsku filozofiu. Pre našu hlavnú tému je podnetné najmä tvrdenie, že tento dialóg bol napísaný ako spájací článok pre internú diskusiu ohl'adom učenia v Platónovej Akadémii (Thesleff 2009, 362)

${ }^{16}$ Porov. Baynham, Tarrant $(2013,2015)$.

${ }^{17}$ Porov. Plutarchov opis Alkibiadovej krásy (Plutarchos, Alc. 1).

${ }^{18}$ Dover však ukazuje na príkladoch z Platónových dialógov Lysis (Lys. 206d - e) a Charmidés

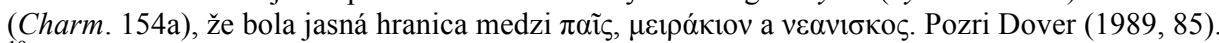

${ }^{19}$ Porov. Dean-Jones $(2013,112)$.

${ }^{20}$ Tento vek sa v aristokratických kruhoch spájal s inštitúciou, ktorá je v gréčtine označovaná ako
} 
Alkibiadés z rovnomenného dialógu sa nachádza na hranici tohto veku, jeho telesný pôvab už odkvitol a nepredstavuje tak pre $z^{2}$ k $^{21}$ potencionálneho milovníka žiadnu hrozbu. Tvrdíme, že Sokrates sa nepribližoval k mladému Alkibiadovi práve zo strachu pred spomínanými účinkami Erosa, teda pred stratou rozumnej mysle. Napriek tomu, že Sokrates uvádza ako dôvod svojho konania daimonion, autorov dôraz na dramatické vykreslenie budúceho aténskeho politika (krása, pôvab, vek), svedčí o Sokratových obavách z priamej konfrontácie ( $\mathrm{z}$ očí do očí) s krásnym mladíkom. Nazdávame sa, že práve $\mathrm{v}$ týchto častiach dialógu sa manifestuje pôvodný význam zraku, ktorý implikoval akúsi bázeň a strach pred bohom.

Stále sme však nezodpovedali otázku, prečo sa Sokrates vyhýbal práve Alkibiadovi? Nazdávame sa, že odpoved' na ňu môže vychádzat' z kontextu Platónových dialógov (Sokratov špecifický vzt’ah k Alkibiadovi v dialógu Hostina ${ }^{22}$ ), a zároveň z historického kontextu (Sokratovo stretávanie s Alkibiadom, ktorého si dejiny pamätajú aj vd'aka množstvu bezbožných činov, by mohlo l'ahko dosvedčovat' znenie Sokratovej obžaloby ${ }^{23}$ ).

$\mathrm{Na}$ tomto mieste si musíme položit otázku, ako vlastne Platónov Sokrates prekonáva archaický koncept Erosa, pričom treba brat' do úvahy predpoklad, že Sokratova výchova sa realizuje prostredníctvom živého rozhovoru (z očí do očí), teda nemôže nastat' situácia, ked' sokratovský vychovávatel' sa nenachádza $\mathrm{v}$ priamej konfrontácii so svojím žiakom. Živou súčast’ou tejto otázky sa stáva d’alší problém, na ktorý vo všeobecnosti upozorňuje Nussbaumová a ktorý sa netýka žiaka, ale filozofa ako učitel'a: Musí filozof nevyhnutne niekoho konkrétneho stretnút' a milovat', aby bol schopný filozofovat?'? (Nussbaumová 2003) Musí vychovávatel' nevyhnutne niekoho konkrétneho stretnút' a milovat', aby bol schopný vychovávat?

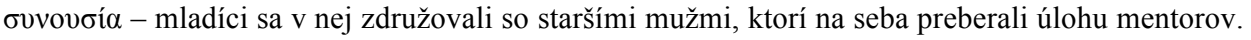

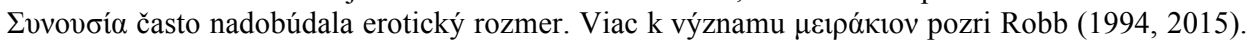
Dané obdobie sa podl'a niektorých autorov končilo vtedy, ked' mladému mužovi začala rást' brada. Pozri Dover (1989, 89) aj Platón (Prot. 309a).

${ }^{21}$ Aj v dialógu Charmidés nachádzame priamu súvislost' medzi pohl'adom do očí a erotickou

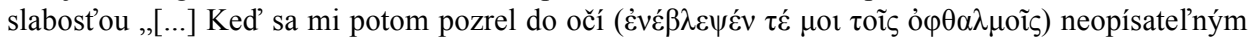
spôsobom a práve mi chcel položit' otázku, pričom sa všetci v palestre tlačili okolo nás, vtedy, môj šlachetný priatel', som uvidel pod odevom jeho telo, vzbíkol som a už som bol celý bez seba

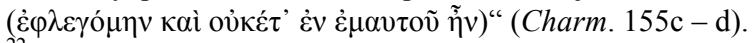

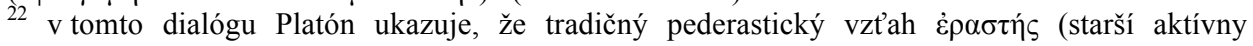

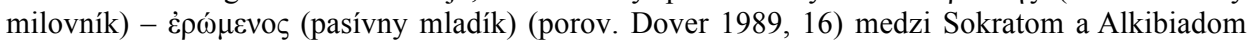
mení svoju podobu - Alkibiadés sa stáva milovníkom a Sokrates, naopak, objektom erotického záujmu (Platón, Symp. 217c).

${ }^{23}$ Antické zdroje dosvedčujú, že Alkibiadés bol obvinený zo zavádzania nových božstiev a vo všeobecnosti sa správal bezbožne (známe zničenie hermoviek); (pozri Plutarchos, Alc. 4).

${ }^{24}$ Nussbaumová sa zaoberá touto otázkou takmer v celej Kř hkosti dobra (najmä s. 408 - 425). 
Z Platónových dialógov vieme, že sokratovská výchova vyžaduje priamu konfrontáciu - zvyčajne ide o dialóg dvoch osôb. Akým spôsobom však Sokrates miluje, aby ho neoslabila moc spomínaného Erosa?

O tom, že Sokratovi robilo problému krotit' prudkú erotickú vášeň ku krásnemu Alkibiadovi, sa dozvedáme aj z iných antických zdrojov. Athénaios nás vo svojom diele Hodujúci sofisti informuje, že Sokrates dokonca plakal, ked' sa mu nepodarilo zviest' Alkibiada (porov. Ath. $219 \mathrm{c}-\mathrm{f}$ ). Z Aristoxenovho svedectva ${ }^{25}$ zasa vieme, že Sokrates vonkoncom nepredstavoval ideál cnostného a umierneného filozofa -

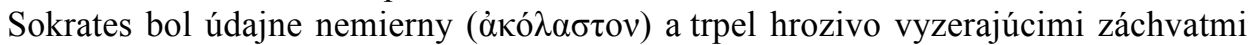
zúrivosti, pri ktorých sa nezdržal žiadneho slova ani skutku (Fr. 54a-b, Wehrli). Fragment z Faidónovho dialógu Zophyros tiež odkazuje na Sokratovu prirodzenú nemiernost', ktorú sa naučil rokmi ovládat' prostredníctvom racionálneho tréningu. ${ }^{26}$ A napokon z Platónovho dialógu Charmidés sa dozvedáme, že Sokrates neváha použit' klamstvo, ${ }^{27}$ len aby sa mohol rozprávat' $\mathrm{s}$ krásnym mladíkom. Navyše Platónov Sokrates sa nikde explicitne nepriznáva, že disponuje cnost'ou. Pokial' teda Sokrates nedisponuje cnost'ou a je prirodzene náchylný $\mathrm{k}$ erotickej žiadostivosti, môžeme tvrdit', že rovnako ako jeho žiak, tak aj on sa musí v pedagogickom vzt'ahu niečomu učit'. Toto tvrdenie podporuje aj koncept tradičného pederastického vzt’ahu,

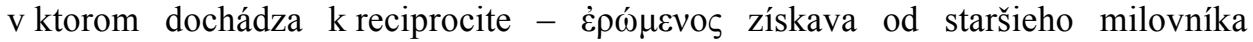

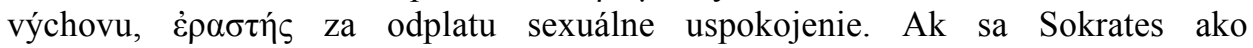
vychovávatel' vzdá sexuálnych pôžitkov, čo získa v tomto vzt’ahu?

Ked' sa vrátime naspät' k dialógu Alkibiadés I., môžeme si všimnút', že jeho prvá polovica obsahuje podobnú argumentačnú líniu, akú nachádzame v dialógu Hostina a ktorá sa objavuje pri pokuse o charakteristiku Erosa. Charakter Erosa v druhom uvedenom dialógu - ten, ktorý je vždy medzi vedením a nevedením, medzi strádaním a plnost’ou (porov. Symp. 204b - c) - sa odvíja od tvrdenia, že kto je múdry, nehl'adá múdrost', a rovnako ani ten, kto si neuvedomuje svoj nedostatok (svoju nevedomost'), netúži po tom, čoho nedostatok necíti (Symp. 204a). V prvom spomínanom dialógu Sokrates konfrontuje Alkibiada s rovnakým problémom. ${ }^{28}$

Sokrates: Je možné, že by si sa bol niekedy niečo naučil, alebo vynašiel, keby si sa to nebol chcel naučit', alebo to sám nechcel ${ }^{29}$ hl'adat'?

Alkibiadés: To nie je možné.

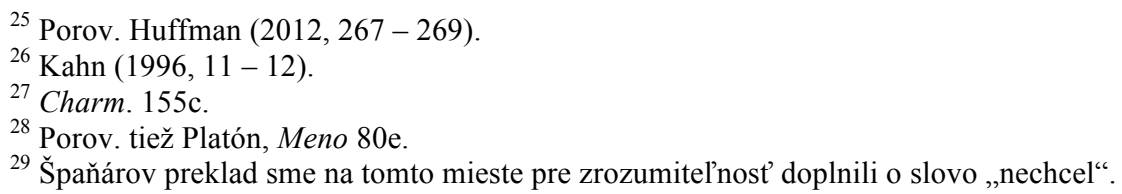


Sokrates: a čo, bol by si chcel hl'adat' alebo sa učit' to, o čom si sa domnieval, že to vieš?

Alkibiadés: Zaiste nie. (Platón, Alc. I. 106d).

Hoci v tomto dialógu Platón neformuluje riešenie nastoleného problému prostredníctvom priamej analógie s Erosom tak ako v Hostine, Eros je pri hl'adaní správnej odpovede stále prítomný a ukazuje sa prostredníctvom takzvanej optickej paradigmy, ${ }^{30}$ ktorá nadobúda $\mathrm{v}$ druhej polovici dialógu špecifický platónsky charakter. Pohl'ad do očí milovanej osoby opúšt’a archaický koncept hrôzostrašného Erosa $^{31}$ a stáva sa vyjadrením pedagogickej reciprocity medzi žiakom a učitel'om. Sokrates ako vychovávatel' sa nestará o veci, ktoré patria Alkibiadovi (vizuálna krása), ale o Alkibiada samého (duša). Alkibiadés ako žiak zasa musí prostredníctvom Sokrata spoznat' sám seba, aby nadobudol poznanie o všetkých ostatných veciach (Alc. I. 129a). Inak nikdy nebude schopný dosiahnut' stav ustavičnej túžby po d'alšom poznávaní (strádanie), hoci už bude disponovat' nejakou sumou poznania (plnost'). Pedagogická reciprocita je v tomto dialógu vyjadrená optickou metaforou, ktorá odkazuje na to, že aj sám Sokrates sa v procese videnia

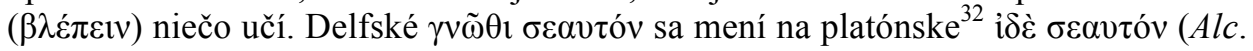
I. $132 \mathrm{~d})$.

„Sokrates: Uvažujme teda, na aké predmety sa musíme pozerat', aby sme nevideli len predmet, ale aj samých seba (i் $\mu \tilde{\alpha} \varsigma \alpha \hat{\tau} \tau o v ́ \varsigma)$ ?

Alkibiadés: Zrejme, Sokrates, že do zrkadiel a do podobných vecí.

Sokrates: Správne hovoríš. Nie je naše oko, ktorým vidíme

( $\tau \tilde{\omega}$ ỏ $\varphi \theta \alpha \lambda \mu \tilde{\omega} \tilde{\omega} \dot{o} \rho \tilde{\omega} \mu \varepsilon v)$, taký druh zrkadla?

Alkibiadés: Isteže.

Sokrates: Všimol si si teda, že tvár toho, kto sa pozerá do oka druhého, ukazuje sa v naproti stojacom oku ako v zrkadle, v tom, čomu my hovoríme zrenica, pretože to je akýsi obrázok toho, kto

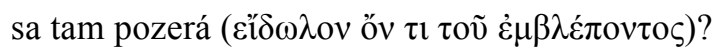

Alkibiadés: Máš pravdu.

\footnotetext{
${ }^{30}$ Wohl (2012).

${ }^{31}$ Porov. Platón, Alc. I. 130e.

${ }^{32} \mathrm{~V}$ súvislosti s dialógom Alkibiadés I. zámerne používame označenie „platónsky“, a nie Platónov. Porov. poznámku pod čiarou č. 15.
} 
Sokrates: Ked' sa teda oko pozerá na iné oko a díva sa do jeho najlepšej časti, do tej, ktorou oko vidí, videlo by takto samo seba

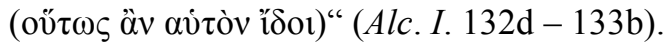

Videnie je u Platóna analógiou myslenia. Ak si spomenieme na podobenstvá z dialógu Štát, môžeme si všimnút', že vo všetkých troch existuje dôležitá relácia medzi videním a myslením (tma v jaskyni $v s$. svetlo vonku, slnko / idea Dobra ako to, čo umožňuje videnie / poznanie, oblast' viditel'ného vs. oblast' myslitel'ného na úsečke). Tieto podobenstvá však referujú na zrak a videnie ako na myslenie, ktoré je oproti pravému poznaniu kategoricky nižšie (vidíme tiene, obrazy na vode, premenlivý svet rastlín a živočíchov; Resp. VI. 509e - 510a). My sa však nazdávame, že ked' Platón hovorí o videní, pri ktorom je prítomný Eros, ${ }^{33}$ odkazuje na myslenie, ktoré vedie k vyššiemu poznaniu. Vo Faidrovi sa „erotický“ pohl'ad stáva dokonca akousi metaforou dialektického procesu alebo filozofickej $\theta \varepsilon \omega \rho{ }^{\prime} \alpha,{ }^{34}$

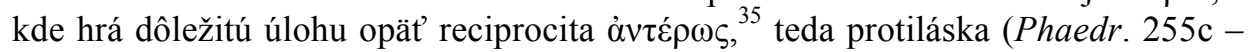
255d).

Sokrates sa pozerá Alkibiadovi do očí. Čo v tomto recipročnom procese Sokrates ako vychovávajúci získava? Alebo inak povedané: Akým spôsobom vychováva spupný Alkibiadés filozofa Sokrata?

Sokrates sa pozerá sa do očí krásneho Alkibiada a nesmie sa nechat' ovládnut' divokou a hrôzostrašnou silou archaického Erosa. Prostredníctvom Alkibiada a jeho výnimočnej krásy spoznáva svoje vlastné limity. Alkibiadov Eros, teda Alkibiadova túžba má na Sokrata naozaj pedagogické účinky - oči milovaného sa stávajú prostriedkom vlastnej sebareflexie a nevyhnutnou podmienkou Sokratovho filozofického sebautvárania, ktorého ciel'om je pretvorit' erotický vzt'ah na priatel'skú lásku. ${ }^{36}$

\footnotetext{
${ }^{33}$ Ide o špecifický platónsky koncept Erosa ako daimona, ktorý je prostredníkom medzi l’udským a božským poznaním a ktorého ekvivalent predstavuje Sokratova filozofická činnost' (porov. Platón, Symp. 202e).

${ }^{34}$ Diváctvo ako metaforu filozofickej činnosti nachádzame v zlomku z diela Platónovho žiaka Herakleida Pontského v Pytagorovom životopise u Diogena Laertského (ap. Diog. Laert., Vit. VIII. 1.). Porovnaj aj Platón, Theaet. $173 \mathrm{c}-174 \mathrm{c}$, kde je filozofia vnímaná ako $\theta \varepsilon \omega p i ́ \alpha$, ktorá sa zakladá na pozorovaní nebeských telies.

${ }^{35}$ Vlastos sa nazdával, že Platónova erotická teória nekladie žiadny dôraz na lásku, ktorú cíti milovaný (porov. Vlastos 1973, 32). Na základe uvedeného zlomku z Faidra však nemôžeme súhlasit' s týmto tvrdením. Proti Vlastosovmu názoru argumentuje Obdrzalek (2013, 222 - 226).

${ }^{36} \mathrm{~V}$ dialógu Alkibiadés I. sa filia stáva podmienkou jednoty (Alc. I. 127b).
} 
O tom, že filia ako priatel'stvo je v Platónovej filozofii d’alším stupňom

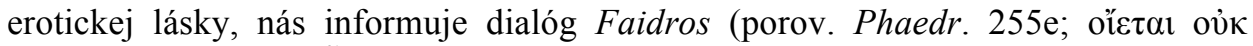

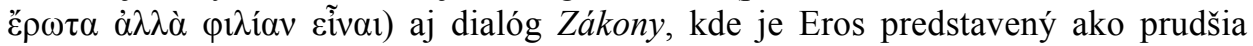
verzia filie, teda podmienkou vzniku filie je skrotenie divokej túžby ( $\dot{\pi} \imath \theta v \mu i ́ \alpha)$, ktorá sa podl'a Platóna spája s erotickou láskou (Leg. VIII. 837a-d).

Na základe uvedeného môžeme povedat', že odpoved' na našu otázku, ktorú pôvodne sformulovala Nussbaumová, teda či musí vychovávatel' milovat', aby mohol vychovávat', je kladná. Vo vzt'ahu žiak a vychovávatel' musí milovat' správnym spôsobom nielen Sokrates, ale aj Alkibiadés. ${ }^{37}$ Ak sa Sokrates zriekne archaického Erosa, musí sa ho zrieknut' aj jeho žiak. ${ }^{38} \mathrm{~V}$ závere Platónovej Hostiny sa však dozvedáme, že Alkibiadova prognóza o tom, že nakoniec sa on stane Sokratovým pedagógom (Alc. I. 135d), nadobúda tragický význam. Alkibiadés sa stáva milovníkom v tradičnom zmysle slova (porov. Symp. 217c), stáva sa tým, kto opúšta hranice platónskeho Erosa, aby sa vrátil k tomu archaickému, pri ktorom milovníka pohl'ad na fyzickú krásu oslabuje. Sokratov vzt'ah k Alkibiadovi by sme mohli interpretovat' aj v intenciách Platónovho rebríka lásky (Porov. Symp. 210a-212b) tento vzt’ah sa stáva metaforou výstupu po jednotlivých stupňoch rebríka lásky, teda od túžby po krásnom tele až po túžbu po krásnej duši. Treba však mat' na mysli, že pre sokratovského filozofa je nesmierne dôležitý aj prvý stupeň tohto rebríka, teda sprvoti nespútaná túžba po krásnom Alkibiadovi.

Platón teda $\mathrm{v}$ istom zmysle využíva koncept archaického Erosa. Stále je prítomné úzke prepojenie medzi zrakom a Erosom, avšak nadobúda novú podobu. Zatial' čo v predchádzajúcej tradícii dominovala predstava, že Eros prostredníctvom zraku oslabuje fyzickú alebo duševnú silu hrdinu, Platón vo svojej filozofii vníma pohl’ad do očí milovanej osoby opačne - ako niečo, čo môže človeka vnútorne posilnit'. Sokrates vd’aka konfrontácii s krásnym a žiadostivým Alkibiadom podstupuje

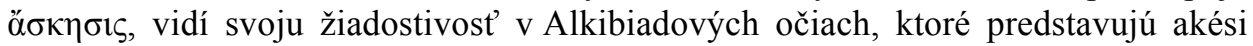
zrkadlo. Zrkadlo, vd'aka ktorému sa filozof sebareflektuje, začína pracovat' so žiadostivostou a prechádza na d’alší stupeň rebríka lásky, teda sa stáva morálne zdatnejším. Platón opúšt’a nebezpečného archaického Erosa, iba ak správne miluje nielen vychovávatel', ale aj žiak. Spojenie „správne milovat" v tomto zmysle

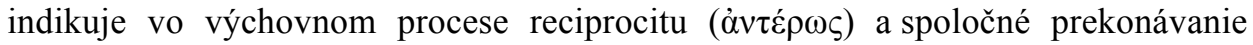
vášnivej erotickej lásky s ciel'om nadobudnút' filiu. Je potrebný priamy pohl'ad z očí do očí, z duše do duše. ${ }^{39}$

37 V dialógu Hostina sa o tomto procese dozvedáme opät' prostredníctvom optickej metafory. Porov. Platón, Symp. 218d - 219a.

${ }^{38}$ Dôležitú úlohu v tomto pedagogickom vzt'ahu hrá aspekt dobrovol'nosti - žiak musí dobrovol'ne akceptovat' Sokratov spôsob výchovy. Teloh uvádza ako príklad človeka, ktorý nechce Sokrata počúvat' (nechce sa nechat' vychovávat') sofistu Trasymacha, pozri Teloh 1986, 82 - 97.

${ }^{39}$ Tento aspekt Sokratovej výchovy, teda potreba sústavných stretnutí so Sokratom, potvrdzuje aj Xenofón a uvádza, že Alkibiadés a Kritias boli umiernení, kým sa stretávali so Sokratom. Porov. Mem. I. 2.15. 


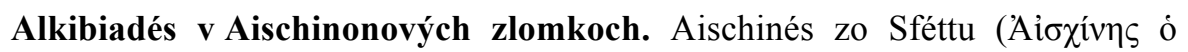

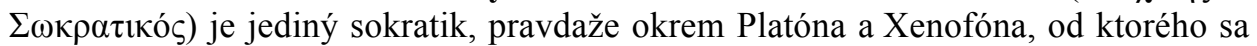
nám zachovali substanciálne literárne pamiatky, teda najmä rozsiahle fragmenty $\mathrm{z}$ dialógov Alkibiadés ${ }^{40}$ a Aspasia. Jeho významné postavenie v rámci sokratovského krúžku dokumentuje aj sám Platón - Aischinés je prítomný na Sokratovej obžalobe (Apol. 33e) a rovnako trávi so Sokratom jeho posledné chvíle predtým, než vypije jed (Phaed. 59e). Diogenes Laertský tento úzky vzt’ah potvrdzuje a zdôrazňuje, že zo všetkých sokratovských dialógov sú pravé iba Platónove, Xenofónove, Antisthénove a tie Aischinove (Diog. Laert., Vit. II. 7. 64).

Pre náš príspevok je dôležitý najmä fakt, že Aischinés sa zvykne pokladat' za pôvodcu literárnej koncepcie sokratovského Erosa. ${ }^{41} \mathrm{Na}$ druhej strane je zrejmé, že akýsi leitmotív celého Aischinovho diela je téma zdokonal'ovania samého seba, ${ }^{42}$

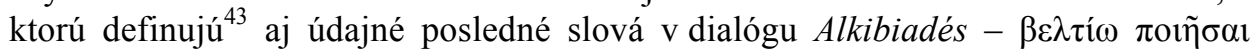
(„urobit' lepším“). Ústrednou témou Aischinovho diela je teda podl'a všetkého paideia. ${ }^{44}$ Akú podobu nadobúda paideutický vzt’ah medzi Alkibiadom a Sokratom u Aischina a akú úlohu hrá v tomto vzt’ahu Eros?

Napriek fragmentárnosti Aischinovho diela sa zdá, že jeho portrét Alkibiada do vel'kej miery korešponduje so závermi, ktoré sme predstavili v predošlej časti.

Paideutický vzt’ah medzi Sokratom a Alkibiadom je opät' recipročný, pričom Alkibiadés - podobne ako u Platóna - pomáha Sokratovi, aby sa mohol stat'

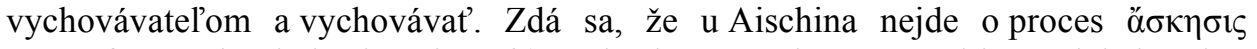
a transfor-máciu žiadostivosti na filiu. Ide skôr o pozitívne využitie erotickej túžby, ktorá vedie Sokrata $\mathrm{k}$ akejsi božskej extáze, ba až $\mathrm{k}$ vzrušeniu, aké zažívajú bakchantky. „Láska, ktorou som sa práve zalúbil do Alkibiada, mi umožnila zažit'

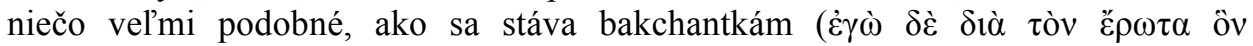

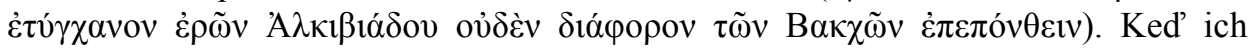

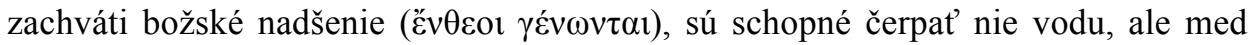
a mlieko zo studní, ktoré zostávajú pre ostatných l’udí celkom suché. a naozaj som

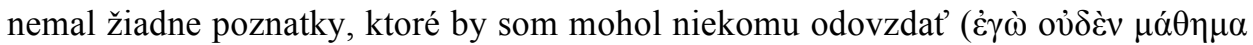
$\dot{\varepsilon} \pi 1 \sigma \tau \alpha \dot{\alpha} \mu \varepsilon v 0 \varsigma$ ô $\delta 1 \delta \alpha \dot{\xi} \alpha \varsigma$ öv$\theta \rho \omega \pi \mathrm{ov})$ a takto byt' užitočný. Napriek tomu som bol presvedčený o tom, že iba jednoduchým stretávaním s ním by som ho mohol urobit'

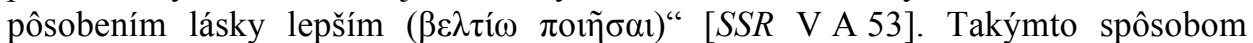
opísané účinky Erosa môžeme považovat’ za akýsi božský údel, chápaný skôr ako

${ }^{40}$ Podl'a Dittmara bol tento dialóg pravdepodobne napísaný medzi rokmi 394 - 393 a 391 - 390 pred Kr., zatial' čo Platónov Alkibiadés I. vznikol až neskôr, medzi rokmi $340-330$ pred Kr.. (Dittmar 1912, 174).

${ }^{41}$ Kahn $(1994,87)$.

${ }^{42}$ Döring hovorí o protreptickej úlohe Aschinových dialógov, ktorých ciel’om je viest' $\mathrm{k}$ „Besser-Werden“ a „Besser-Machen“. Porov. Döring $(1984,17)$.

${ }^{43}$ Porov. Joyal $(1993,267)$.

44 Dialóg sa odohráva v prostredí telocvične $(\pi \alpha \lambda \alpha i ́ \sigma \tau \rho)$, ktorá odkazuje na dôležitú súčast'

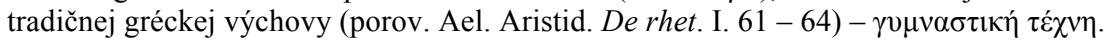


dar $(\theta \varepsilon \alpha ́$ $\mu$ oĩpa), ktorý odkazuje na oblast' iracionálneho. Táto oblast' predstavuje ostrý kontrast $\mathrm{k}$ výchove prostredníctvom $\tau \dot{\chi} \chi v \eta, \mathrm{ku}$ ktorej viedol Aischinovho Alkibiada Themistoklés (porov. [SSR V A 49]) a ktorá nemala na Alkibiada takmer žiadny pozitívny vplyv. Prečo má Sokratova výchova na Alkibiada také účinky?

Jednou z hlavných zásad sokratovskej výchovy - na rozdiel od tých zásad, ktorými sa pri Alkibiadovej výchove pravdepodobne riadil Themistoklés - je nadobudnutie priatel'stva takým spôsobom, že Sokrates prispôsobí svoje správanie (resp. výchovu) charakteru budúceho žiaka / priatel'a. ,[...] Je vel'mi dôležité, aby sa človek prispôsobil svojím správaním druhému a mal správny prístup k l’ud’om, lebo násilím si priatel'a ani nezískaš, ani nepripútaš, toto zvieratko sa dá chytit' a skrotit' len dobrými skutkami a milým správaním“ (Mem. III. 11. 10). Túto zásadu nachádzame tiež v Platónovom dialógu Faidros (Phaedr. 271b) - dobrý rečník disponuje mnohoobratnost'ou ( $\pi$ o $\lambda v \tau \rho o \pi i ́ \alpha)$, teda je schopný podla typu poslucháča volit' vhodné slová, ktoré vedia „,pohnút"“ konkrétnym l'udským charakterom.

Keby sme aj v prípade Aischina pokladali Alkibiada za symbol archaickej paideie (Antisthenés ho dokonca priamo prirovnáva $\mathrm{k}$ homérskemu paideutickému vzoru Achilleovi, porov. [SSR V A 199]), resp. archaického Erosa, tak by bolo zrejmé, prečo sa Aischinov Sokrates necháva ovládnut' iracionálnou a bakchickou silou lásky - Sokrates sa prispôsobuje Alkibiadovi s ciel'om obrátit' jeho srdce $\mathrm{k}$ dobru

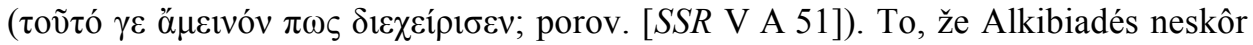
od Sokrata prebral tento spôsob komunikácie, potvrdzuje Plutarchos v Alkibiadovom životopise (Plutarchos, Alc. 23).

Záver. Mohli by sme povedat, že Alkibiadés je jednou z najzaujímavejších postáv v sokratovskej literatúre ako takej. Jeho ambivalentná povaha - vyniká nad všetkých l'udí rovnako v cnosti, ako aj v neresti - podnietila Sokratových žiakov $\mathrm{k}$ tomu, aby tento jedinečný charakter začlenili do svojich filozofických náuk, pričom „postava Alkibiadés“ spravidla referuje na problémy, ktoré sa spájajú so sokratovskou paideiou.

Keby sme si však opät' položili otázku, ako spupný Alkibiadés pozitívne pôsobí na filozofa Sokrata, odpovede sa budú rôznit'. Analýza pedagogicko-pederastického vzt’ahu v súvislosti so zmenou v optickej paradigme (archaický Eros, ktorý odoberá hrdinovi životnú silu vs. platónsky Eros, ktorý hrdinu posilňuje) u Platóna sa pokúsila ukázat', že Alkibiadova prudká láska vychováva Sokrata k tomu, aby vedel čelit' nástrahám archaického Erosa a transformoval erotickú lásku ku krásnemu telu na priatel'skú lásku ku krásnej duši. Hoci u Aischina ide tiež o pozitívne využitie erotickej túžby, toto využitie má inú podobu. Uvedená túžba vedie Sokrata k božské-mu nadšeniu ( $\check{v} \theta \varepsilon o r ~ \gamma \varepsilon ́ v \omega v \tau \alpha l$ ), vd'aka ktorému je schopný Alkibiada vychovávat' a robit' ho lepším ( $\beta \varepsilon \lambda \tau i ́ \omega \pi$ oiñ $\sigma \alpha$ ). Bez vzájomnej túžby by to však nebolo možné - Sokrates je teda bez lásky k Alkibiadovi bez poznatkov (

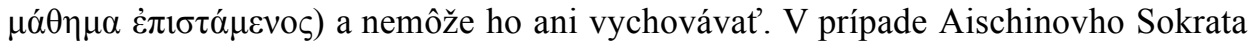
sa tiež nazdávame, že dôležitú úlohu vo výchove hrá najmä vychovávatel'ova poly- 
trópia - Sokrates prispôsobuje výchovu k cnosti charakteru daného žiaka, žiadostivého Alkibiada vychováva iracionálnym spôsobom prostredníctvom božskej sily a vd’aka božskému údelu ( $\theta \varepsilon \alpha ́$ õo $\alpha)$.

Zatial' čo v prípade Aischinovho portrétu Sokrata v prospech našej hlavnej tézy svedčí explicitná textová evidencia - Sokrates dokáže učit' vd’aka láske k Alkibiadovi, v prípade platónskeho Sokrata je zdôvodnenie danej tézy skôr vecou širšej interpretácie, ktorá musí ústretovo akcentovat' filozofický kontext $\mathrm{z}$ viacerých Platónových, resp. platónskych dialógov. Ak však zoberieme do úvahy Kahnovo tvrdenie - zakladatel'om sokratovskej koncepcie Erosa je práve Aischinés - pokladáme za relevantné vnímat' skúmaný problém práve cez prizmu Aischinových myšlienok.

\section{Literatúra:}

BAYNHAM, E., TARRANT, H. (2012): Appendix 1. Fourth-Century Politics and the Date of the Alcibiades I. In: Johnson, M. \& Tarrant, H. (eds.): Alcibiades and the Socratic LoverEducator. London: Bristol Classical Press, 215 - 222.

BEEKES, R. (2010): Etymological Dictionary of Greek. Vol. 1. Leiden: Brill.

DEAN-JONES, L. (2013): The Child Patient of the Hippocratics: Early Pediatrics? In: Grubbs, J. E. - Parkin, T. - Bell, R. (eds.): The Oxford Handbook of Childhood and Education in the Classical World. Oxford, New York: Oxford University Press, 108 - 124.

DITTMAR, H. (1912): Aischinés von Sphettos. Studien zur Literaturgeschifte der Sokratiker. Berlin: Weidmannsche Buchhandlung.

DOVER, K. J. (1989): Greek Homosexuality. Cambridge - Massachusetts: Harvard University Press.

DÖRING, K. (1984): Der Sokrates des Aischinés von Sphettos und die Frage nach dem historischen Sokrates. Hermes, 112 (1), 16 - 30.

FLACHBARTOVÁ, L. (2014): Kynické parrhesiastické praktiky. Diogenova performatívna múdrost'. Filozofia, 69 (10), 835 - 846.

FLACHBARTOVÁ, L., SISÁKOVÁ, O., SUVÁK, V. (2016): Starost' o seba: Antické problematizácie života a súčasné myslenie. Prešov: Vydavatel'stvo Prešovskej univerzity.

FOUCAULT, M. (2002): Le courage de la verité. Le gouvernement de soi et des autres II. Cours au Collège de France. Paris: Gallimard, Seuil.

FOUCAUlT, M. (2008): Le gouvernement de soi et des autres. Cours au College de France. Paris: Gallimard, Sueuil.

FRIEDLÄNDER, P. (1921 - 1923): Der Grosse Alcibiades, I., II., Bonn: Friedrich Cohen.

GIANNANTONI, G. (ed.) (1990): Socratis et Socraticorum Reliquiae. 4 Vol. Napoli: Bibliopolis.

GORGIAS (2016): Chvála Heleny. Preložili A. Kalaš, Z. Zelinová. Filozofia, 71 (5), 425 - 430.

HADOT, P. (1987): Exerci ces Spirituels et Philosophie Antique. Paris: Etudes Augustiniennes.

HEJDUK, T. (2007): Od Eróta k filosofii. Studie o Erótu se zretelem k Sókratově filosofii. Praha: Pavel Mervart.

HUFFMAN, C. A. (2012): Aristoxenus' Life of Socrates. In: Huffman, C. A. (ed.): Aristoxenus of Tarentum: Discussion. New Brunswick: Transaction Publishers, 251 - 281.

CHANTRAINE, P. (1968): Dictionnaire Étymologique de la Langue Grecque, Histoire des Mots. Tome I. Paris: Éditions Klinckseck. 
JIRSA, J. (2007): Alcibiades' speech in the Symposium and its origins. In: Havlíček, A. - Karfík, F. (eds): Plato's Symposium. Praha: Oikoymenh, 279 - 292.

JOHNSON, M. - TARRANT, H. (eds.) (2012): Alcibiades and the Socratic Lover-Educator. London: Bristol Classical Press.

JOYAL, M. A. (1993): The Conclusion of Aeschines' Alcibiades. In: Rheinisches Museum für Philologie Neue Folge, 136 (3/4), 263 - 268.

KAHN, CH. H. (1994): Aeschines on Socratic Eros. In: Vander Waerdt, P. A. (ed.): The Socratic Movement. Ithaca: Cornell University Press, $87-106$.

KAHN, CH. H. (1996): Plato and the Socratic Dialogue: The Philosophical Use of a Literary Form. Cambridge: Cambridge University Press.

KALAŠ, A., SUVÁK, V. (2013): Antisthenis Fragmenta. Bratislava: Univerzita Komenského v Bratislave.

LAMPE (2015): Rethinking Aeschines of Sphettus. In: Zilioli, U. (ed.): From the Socratics to the Socratic Schools. New York - London: Routledge Press, $61-81$.

MURRAY, O. (ed.) (1994): Sympotica: a Symposium on the Symposion. Oxford: Clarendon Press.

NEHAMAS, A. (2000): The Art of Living: Socratic Reflections from Plato to Foucault. Berkeley: University of California Press.

NUSSBAUMOVÁ, M. C. (2003): Křehkost dobra. Přeložili D. Korte a M. Ritter. Praha: OIKOYMENH.

OBDRZALEK, S. (2013): Socrates on Love. In: Bussanich, J. - Smith, N. D. (eds.): The Bloomsbury Companion to Socrates. London: Bloomsbury Academic, 210 - 232.

ROBB, K. (1994): Litteracy and Paideia in Ancient Greece. Oxford: Oxford University Press.

RUDHARDT, J. (1986): Le rôle d'Éros et d'Aphrodite dans les cosmogonies grecques. Paris: PUF.

SELLARS, J. (2009): The Art of Living: The Stoics on the Nature and Function of Philosophy. London: Duckworth.

SNELL, B. (1953): The Discovery of The Mind: The Greek Origins of European Thought. Oxford: Basil Blackwell.

STEFANINI, L. (1949): Platone I. - II., Padova: Cedam.

SUVÁK, V. (2014): Sókratovská therapeia: Úloha Sókrata. Filozofia, 69 (10), 824 - 834.

SUVÁK, V. (2016): Sókratovská therapeia: Platónov Charmidés 153a - 158d. Filozofia, 71 (5), $357-368$.

SUVÁK, V. (2017): Umenie života medzi Sókratom a Epiktétom. Filozofia, 72 (2), 81 - 91.

SUVÁK, V. (2018): Socratic Therapy as Taking Care of the Self and Others. In: Suvák, V. (ed.): Care of the Self. Ancient Problematizations of Life and Contemporary Thought. Leiden Boston: Brill.

TELOH, H. (1986): Socratic Education in Plato's Early Dialogues. Notre Dame - Indiana: University of Notre Dame Press.

THESLEFF, H. (2009): Platonic Patterns. a Collection of Studies by Holger Thesleff. Las Vegas: Parmenides Publishing.

VÍTEK, T. (2010): Prameny Eróta v Platónově Symposiu. Aithér, II. (3), 49 - 70.

VLASTOS (1973): Platonic Studies. Princeton: Princeton University Press.

WOHL, V. (2012): The Eye of the Beloved: Opsis and Eros in Socratic Pedagogy. In: Johnson, M. - Tarrant, H. (eds.) (2012): Alcibiades and the Socratic Lover-Educator. London: Bristol Classical Press, $45-60$. 
WOLLNER, U. (2010): Starostlivost' o seba v Xenofóntovom diele MEMORABILIA. In: Suvák, V. (ed.): Sebapoznanie a/ko starost' o seba. Prešov: Filozofická fakulta Prešovskej univerzity, $32-78$.

ZVARÍK, M. (2018): Etika ako prvá filozofia Pierra Hadota. Ostium, 14 (1),

(http://ostium.sk/language/sk/etika-ako-prva-filozofia-podla-pierra-hadota/; navštívené 22.

10. 2018).

Štúdia je súčast'ou riešenia grantovej úlohy VEGA: 1/0017/17 Aischinés a sokratovský dialóg.

Zuzana Zelinová

Filozofická fakulta UK v Bratislave

Katedra filozofie a dejín filozofie

Šafárikovo nám. 6

81499 Bratislava 1,

Slovenská republika

e-mail: zelinova13@gmail.com

\section{Andrej Kalaš}

Filozofická fakulta UK v Bratislave

Katedra filozofie a dejín filozofie

Šafárikovo nám. 6

81499 Bratislava 1

Slovenská republika

e-mail: andrej.kalas@uniba.sk 